\title{
PERAN BUDAYA LITERASI DALAM PEMBENTUKAN KARAKTER RELIGIUS ANAK DI KAMPOENG BATJA PATRANG JEMBER
}

\author{
Iqlimah Maulidiyah \\ Institut Agama Islam (IAIN) Jember \\ lidlidiyah97@,Gmail.Com \\ Sarwan \\ Institut Agama Islam (IAIN) Jember \\ sarwaniain15@gmail.com
}

\begin{abstract}
Abstrak
Tujuan penelitian ini adalah untuk mendeskripsikan peran budaya literasi dalam pembentukan karakter religius anak di Kampoeng Batja Patrang Jember. Penelitian ini menggunakan pendekatan kualitatif deskriptif dengan jenis fenomenologi. Pengumpulan data dalam penelitian ini menggunakan teknik observasi, wawancara dan dokumentasi. Analisis datanya menggunakan analisis interaktuf model Miles, Huberman dan Saldana yaitu pengumpulan data, kondensai data, penyajian data, penarikan kesimpulan/verifikasi. Untuk menguji keabsahan data yang diperoleh, peneliti menggunakan triangulasi sumber dan triangulasi teknik. Hasil penelitian ini adalah: (1) karakter membaca yang terbentuk melaui budaya literasi yang telah diterapkan di Kampoeng Batja adalah karakter membaca reseptif, reflektif, skimming dan scanning; (2) budaya literasi di Kampoeng Batja dapat membentuk karakter menulis cerita, menulis ayat-ayat Al-quran, menulis kaligrafi, menulis sinopsis, menulis pantun, kegiatan tersebut dilaksanakan dengan bernuansa keagamaan; (3) karakter berbicara yang terbentuk melaui budaya literasi yang telah diterapkan di Kampoeng Batja adalah karakter berbicara di depan publik dan berbicara interpersonal.
\end{abstract}

Kata Kunci: budaya literasi, karakter religius

\begin{abstract}
The purpose of this study is to describe the role of literacy culture in the creation of the child's religious character in Kampoeng Batja patrang jember. The study uses a descriptive qualitative approach with a type of phenomenon. Data collection in this study uses observation techniques, interviews and documentation. The data analysis uses miles's and huberman and saldana analysis for data collection, data condenser, data presentation, deduction/verification. To test the validity of the acquired data, researchers used source triangulation and technical triangulation. The study is (1) the character reading through the literated cultures already applied in Kampoeng Batja is the character of prescriptive, reflective, skimming and scanning (2) of the literated cultures in the Kampoeng Batja dat forming the character of storywriting, writing of the quran, writing calligraphy, writing synopsis, poetry, The activity was carried out
\end{abstract}




\section{AL-ADABIYAH: Jurnal Pendidikan Agama Islam}

in a religious (3) speaking character through literacy cultures already adopted in Kampoeng Batja is a public speaking and interpersonal speech.

Keywords: literacy culture, religious character

\section{Pendahuluan}

Kampoeng Batja merupakan salah satu wadah yang dapat mengasah keterampilan dan karakter anak yang didalamnya terdapat banyak inovasi baru yang dapat membuat anak merasa nyaman untuk bermain sambil belajar, jadi disana anak-anak tidak hanya bermain saja melainkan anakanak juga dapat meningkatkan kreatifitas dan karakter mereka dengan mengikuti beberapa kegiatan-kegiatan yang terdapat di Kampoeng Batja tersebut. Sehingga anak-anak dengan sendirinya merasa terbiasa dengan budaya literasi yang bertujuan untuk menumbuhkan karakter mereka. Keunikan yang terdapat di Kampoeng Batja yakni dapat dilihat dari tempatnya yang sangat jarang di sebuah perkotaan yang masih menerapkan kampung asri diiringi dengan pojok-pojok baca di setiap kampung nya, hal tersebut sangatlah menarik perhatian masyarakat sekitar untuk mengembangkan karakter dan inovasi belajar anak-anak.

Arus globalisasi sangat kuat terasa disetiap sendi-sendi kehidupan masyarakat berbangsa dan bernegara. Semua sendi kehidupan masyarakat terasa sakit oleh dahsyatnya pengaruh arus globalisasi. Lunturnya nilainilai nasionalisme dan solidaritas adalah salah satu penyakit yang sedang diderita oleh anak negeri ini. Faktor ini pula yang melatarbelakangi munculnya kepedulian terhadap pentingnya pendidikan karakter. ${ }^{1}$

Fakta menarik yakni kebanyakan anak zaman sekarang lebih memilih membaca handphone daripada membaca buku, Jarang dari mereka yang memiliki minat dan motivasi yang tinggi untuk membaca buku. Bahkan tak jarang dari mereka apatis terhadap kebutuhan untuk membaca buku. Hal inilah yang pada akhirnya turut serta membuat perkembangan literasi di 2011), 1

${ }_{1}^{1}$ Maswari Muhammad, Pendidikan Karakter Anak Bangsa, (Jakarta: Baduose Media, 


\section{AL-ADABIYAH: Jurnal Pendidikan Agama Islam}

Indonesia sangat jauh tertinggal dibandingkan negara yang lain di dunia. ${ }^{2}$ Lunturnya budaya membaca pada anak akibat pengaruhnya perkembangan teknologi yang semakin canggih dan semakin pesat, akibat mereka sudah kecanduan dengan canggihnya teknologi. Eksistensi buku sudah mulai tersaingi oleh benda kecil dengan kecanggihan yang sangat luar biasa. Inilah salah satu yang membuat budaya membaca buku di Indonesia semakin rendah.

Dengan adanya pendidikan karakter jelas bertujuan untuk mendidik watak, akal budi, dan aspek-aspek kejiwaan lainnya. Pendidikan karakter lebih mudah dilakukan pada usia muda, sejak usia dini, bahkan ada dugaan bahwa pendidikan karakter sudah dapat dilakukan pada saat bayi masih berada dalam kandungan. ${ }^{3}$ Dalam hal ini pembentukan karakter anak sangat perlu sekali, adapun perkembangan jiwa keagamaan, selain ditentukan oleh faktor ekstern, juga ditentukan oleh faktor intern seseorang. Seperti halnya aspek kejiwaan lainnya, maka para ahli psikologi agama mengemukakan berbagai teori berdasarkan psikologi agama mengemukakan mengemukakan berbagai teori berdasarkan pendekatan masing-masing. Tetapi secara garis bersar nya faktor faktor yang ikut berpengaruh terhadap perkembangan jiwa keagamaan antara lain adalah faktor gereditas,tingkat usia, kepribaidan, dan kondisi kejiwaan seseorang. ${ }^{4}$

Kegiatan di Kampoeng Batja ini merupakan salah satu alternatif agar dapat menumbuhkan karakter religius anak, karena disana kegiatankegiatan nya berbasis religius dan terbuka buat semuanya, yang menjadi unik yakni terdapat kebudayaan literasi didalam pojok-pojok rumah masyarakat, yang mana di Kampoeng Batja tersebut masyarakat dan anakanaknya sangat mendukung dengan berbagai kegiatan yang terlaksana di Kampoeng Batja tersebut,sehingga banyak pengunjung dari luar yang juga antusias untuk mengikuti kegiatan tersebut. Adapun tujuan penelitian ini

\footnotetext{
2 Ibadullah Malawi,dkk, Pembelajaran Literasi Berbasis Sastra Lokal (Magetan:CV.Ae Media Grafika, 2017), 15-17.

${ }^{3}$ Nyoman kutha ratna, Peranan Karya Sastra, Seni, dan Budaya dalam Pendidikan karakter (Yogyakarta:Pustaka Pelajar, 2014), 73.

4 Aat Syafaat, Sohari Saharani, Dkk, Peranan Pendidikan Agama Islam dalam Mencegah Kenakalan Remaja (Jakarta:PT Raja Grafindo, 2008), 159.
} 


\section{AL-ADABIYAH: Jurnal Pendidikan Agama Islam}

adalah Mendeskripsikan budaya literasi dalam pembentukan karakter membaca anak di Kampoeng Batja, mendeskrip-sikan budaya literasi dalam pembentukan karakter menulis anak di Kampoeng Batja an mendeskripsikan budaya literasi dalam pembentukan karakter berbicara anak di Kampoeng Batja.

\section{Tinjauan Literatur}

\section{Budaya literasi}

Secara sederhana, budaya bisa diartikan dengan pikiran; akal budi, hasil. ${ }^{5}$ Kebudayaan berasal dari kata buddhayah (Sansekerta) merupakan bentuk jamak kata buddhi berarti akal. Dalam bahasa Inggris disebut culture dari kata colore (Latin) berarti mengolah, mengerjakan. Dalam kedua istilah, baik bahasa Sansekerta maupun Latin terkandung pengertian tenaga dan kekuatan untuk beraktifitas, sehingga secara luas kebudayaan dapat diartikan sebagai segala bentuk kegiatan manusia yang di hasilkan melalui daya ciptanya. ${ }^{6}$ Jadi, secara umum kebudayaan dapat diartikan seluruh cara hidup suatu masyarakat.dalam hal ini yang di maksud kebudayaan diatas lebih kepada budaya atau didalam kompleks masyarakatnya terlebih dalam hal literasi menulis, membaca dan berbicara.

Menurut Kuntjaraningrat, ada tiga wujud kebudayaan yang pertama kebudayaan Wujud kebudayaan sebagai suatu kompleks dari ide-ide, gagasan-gagasan, nilai-nilai, norma-norma, peraturan-peraturan, dan sebagainya. Yang kedua Wujud kebudayaan sebagai suatu kompleks aktvitas kelakukan berpola dari manusia dalam masyarakatya, yang ketiga Wujud kebudayaan sebagai benda-benda hasil karya manusia atau kebudayaan fisik. ${ }^{7}$

Kaitannya dalam hal diatas tersebut bahwasannya budaya yang dimaksud yakni wujud dari kebudayaan sebagai suatu kompleks dari ide-

5 Tim Penyusun Kamus Bahsa, Kamus Bahasa Indonesia, (Jakarta : Pusat Bahasa Departemen Pendidikan Nasional, 2008), 226.

${ }^{6}$ Nyoman Kuntha Ratna, Peranan Karya Sastra,Seni, dan Budaya dalam Pendidikan Karakter, 188.

7 Riswandi, Imu Komunikasi, (Yogyakarta:Graha Ilmu, 2009), 91-93. 


\section{AL-ADABIYAH: Jurnal Pendidikan Agama Islam}

ide kretif, gagasan-gagasan, dengan diadakannya Kampoeng Batja sebagai wadah anak agar bisa lebih maksimal dalam hal membaca, menulis dan berbicara. Hal tersebut terdapat nilai-nilai tersendiri didalam karakter dan akhlak serta kebiasaan anak .

Literasi adalah keberaksaraan, yaitu kemampuan menulis dan membaca. Selanjutnya, budaya literasi yang dimaksudkan adalah untuk melakukan kebiasaan berpikir yang diikuti oleh sebuah proses membaca dan menulis, yang pada akhirnya proses kegiatan tersebut akan menciptakan karya. ${ }^{8}$ Pengertian literasi selanjutnya berkembang menjadi kemampuan membaca, menulis atau bebas buta huruf. Pengertian literasi selanjutnya berkembang menjadi kemampuan membaca,menulis, berbicara, dan menyimak. ${ }^{9}$ Istilah literasi dikenal pula dengan istilah multiliterasi yakni sebagai keterampilan menggunakan beragam cara untuk menyatakan dan memahami ide-ide dan informasi, dengan menggunakan bentuk-bentuk teks konvensional maupun teks inovatif, simbol, dan multimedia.

Eisner berpendapat bahwa literasi dapat dipandang sebagai cara untuk menemukan dan membuat makna dari berbagai bentuk representasi yang ada disekitar kita. Berdasarkan pandangan ini, Einser mengemukakan bahwa literasi tidak hanya dipandang sebagai kemampuan menagkap makna dari simbol tertulis,melainkan dari berbagai simbol yang mengandung makna yang ada di sekitar kita. Tujuan literasi dalam konteks multiliterasi dalam pandangan Morocco et al adalah untuk membentuk anak yang mampu menguasai beberapa keterampilan diantaranya: keterampilan membaca pemahaman yang tinggi, keterampilan menulis yang baik untuk membangun dan mengekspresikan makna, keterampilan berbicara secara akuntabel, keterampilan menguasai berbagai media digital. Berdasarkan pendapat tersebut dapat disimpulkan bahwa tujuan literasi yakni untuk mengembangkan kemampuan berbehasa, baik secara tulis

8 Mursalim, Penumbuhan Budaya literasi dengan penerapan ilmu keterampilan berbahasa (membaca dan menulis), jurnal fenomena, Vol. 3 No. 1 Juni 2017, 33.

9 Yunus Abidin, Tita Mulyati, Dkk, Pembelajaran Literasi Strategi Meningkatkan Kemampuan Literasi Matematika, Sains,Membaca, dan Menulis, (Jakarta:Bumi Aksara, 2018), 1. 


\section{AL-ADABIYAH: Jurnal Pendidikan Agama Islam}

maupun lisan dengan menggunakan berbagai bentuk media yang salah satunya adalah media digital berbasis tenaga informasi dan teknologi. ${ }^{10}$

Terdapat beberapa macam fokus pembelajaran literasi diantaranya terdapat: fokus teks, fokus berfikir, fokus kelompok dan fokus pertumbuhan. Hal tersebut bertujuan untuk mengetahui beberapa pengetahuan yang telah didapat melalui tulisan untuk mendukung pengembangan membaca mereka. ${ }^{11}$

\section{Karakter Religuis}

Karakter dalam kamus besar bahasa Indonesia berasal dari kata "tabiat", yang berarti watak, sifat kejiwaan, akhlak atau budi pekerti yang membedakan seseorang dengan yang lain. ${ }^{12}$ Sedangkan Menurut kamus besar Bahasa indonesia karakter merupakan sifat-sifat kejiwaan, akhlak atau budi pekerti yang membedakan seseorang dengan yang lain. ${ }^{13}$ Jadi Karakter merupakan ciri khas seseorang atau sekelompok orang yang mengandung nilai, kemampuan, kapasitas moral, dan ketegaran dalam menghadapi kesulitan dan tantangan.

Dalam kaitannya dengan pendidikan, pendidikan karakter dapat dimaknai sebagai pendidikan nilai, pendidikan budi pekerti, pendidikan moral, pendidikan watak, yang bertujuan mengambangkan kemampuan siswa untuk memberikan keputusan baik buruk, memelihara kebaikan, mewujudkan dan menebar kebaikan dalam kehidupan sehari-hari dengan sepenuh hati, jadi dalam hal ini dapat diambil garis besar bahwa pendidikan yang berkaitan dengan proses pembentukan karakter sangat penting sekali bagi bangsa dan negara, khususnya bagi anak-anak bangsa, yang mana

10 Yunus Abidin, Tita Mulyati, Dkk, Pembelajaran Literasi Strategi Meningkatkan Kemampuan Literasi Matematika, Sains,Membaca, dan Menulis, (Jakarta:Bumi Aksara, 2018), 25-28

11 Ibid, 31.

12 Tim Penyusun Kamus Pusat Bahasa, Kamus Bahasa Indonesia, (Jakarta:Pusat Bahasa Departemen Pendidikan Nasional, 2008), 639.

13 Tim Penyusun Kamus Pusat Bahsa, Kamus Bahasa Indonesia, (Jakarta:Pusat Bahasa Departemen Nasional, 2008). 639. 
anak-anak bangsa inilah yang akan meneruskan dan melanjutkan perjuangan bagsa kedepannya. ${ }^{14}$

Pembentukan karakter atau akhlak seeorang pun sesungguhnya dipengaruhi oleh hati, Al-Ghazali menegaskan bahwa hati adalah raja yang mengatur dan mengarahkan semua anggota badan, baik itu akal, nafsu,mata, telinga dan tubuh manusia. ${ }^{15}$

Maka dari itu, pembentukan karakter anak dapat ditentukan melalui lingkungan,pengalaman di sekitarnya serta dapat juga ditentukan melalui hatinya, karena jika lingkungan dan pengalaman anak tersebut sudah baik kemungkinan besar hatinya juga akan mengikuti dalam hal kebaikan pula, begitu juga sebaliknya, maka kebiasaan berkarakter sangat diperlukan sekali untuk menopang pembentukan karakter anak di masa depannya baik itu berkarakter melalui kegiatan literasi maupun kegiatan yang lainnya, Nilai yang perlu dikembangkan melalui pendidikan formal di sekolah terdiri dari 18 yaitu: religius, jujur, toleransi, disiplin, kerja keras, kreatif, mandiri, demokratis, rasa ingin tahu, semangat kebangsaan, cinta tanah air, menghargai prestasi, bersahabat, cinta damai, gemar membaca, peduli lingkungan, peduli sosial, tangung jawab. ${ }^{16}$

Karakter sendiri bertujuan untuk mengumpulkan dari beragam aspek kepribadian yang melambangkan kepribadian seseorang,sehingga seseorang tersebut dapat memberikan kedamaian dalam hidup. ${ }^{17}$ Mulai tahun pelajaran 2011, seluruh tingkat pendidikan di Indonesia harus menyisipkan pendidikan berkarakter, terdapat 18 nilai-nilai yang terkandung dalam pendidikan berkarakter bangsa diatas tadi, salah satu diantaranya yakni kreatif, rasa ingin tahu dan gemar membaca. Hal tersebut apabila

14 Anas Salahudin, Irwanto Alkrienciehie, Pendidikan Karakter Pendidikan Berbasis Agama dan Budaya Bangsa, (Bandung:CV Pustaka Setia, 2017), 41-42.

15 Akhmad Syahril, Pendidikan Karakter berbasis sistem islamic boarding school, (malang:Cv Literasi Nusantara abadi), t.t, 51-54.

16 Abd. Muis Thabrani, Pengantar Dan Dimensi-Dimensi Pendidikan, (Jember : Stain Jember Press, 2013), 125

17 Abudullah ldi, Safarina, Etika Pendidikan Keluarga, Sekolah dan Masyarakat, (Jakarta:PT Raja Grafindo Persada, 2016), 121. 


\section{AL-ADABIYAH: Jurnal Pendidikan Agama Islam}

diimplementasikan dapat dirangkai menjadi membaca,menulis, dan berbicara. ${ }^{18}$

Ada beberapa pembentukan karakter di Kampoeng Batja diantaranya:

a. Pendidikan Karakter Membaca

Nilai-nilai pendidikan karakter tersebut salah satunya terdapat Cinta Damai maksudnya yakni kebiasaan menyediakan waktu untuk membaca berbagai bacaan yang memberikan kebajikan bagi dirinya. Menurut Ma'mur, membaca merupakan kegiatan rutin yang tidak dapat dipisahkan dari gaya kehidupan manusia modern, terlebih lagi dalam dunia pendidikan, membaca adalah proses interaktif yang berlangsung antara pembaca dan teks, sehingga pembaca menggunakan pengetahuan, keterampilan, dan strategi untuk menentukan apa makna yang terkandung di dalam teks. Jadi, tujuan membaca adalah untuk menentukan pengetahuan yang spesifik, keterampilan, dan strategi yang perlu untuk dipahami oleh pembaca.

Adapun Davies dalam jurnal nya"Introducing Reading" menetapkan ada empat jenis membaca yaitu:

1) Membaca reseptif, yang merupakan cepat, membaca otomatis yang kita lakukan ketika kita membaca narasi

2) Membaca reflektif, di mana kita berhenti sejenak merenungkan apa yang telah kita baca

3) Skimming, di mana kita membaca cepat untuk membangun secara umum apa yang terkandung dalam teks

4) Scanning, atau mencari informasi tertentu

Membaca dapat membantu seseorang menjadi sadar tentang perbedaan teks dan strategi yang mereka gunakan untuk membuat makna ketika mereka membaca, memiliki rasa kontrol atas proses mereka sendiri, dan untuk menjadi pembaca kritis sehingga membantu mereka dalam mengembangkan pribadi melalui budaya

18 Retno Listyarti, Pendidikan Karakter dalam Metode Aktif, Inovatif, dan Kreatif, (Jakarta:Erlangga, 2012), 5-9. 
baca tulis tersebut. ${ }^{19}$ Membaca juga dapat menambah kosa kata dan pengetahuan akan tata bahasa dan sintaks, yang penting lagi membaca mempekenalkan kita pada banyak ragam ungkapan kreatif, dan dengan demikian memepertajam kepekaan linguistik dan kemampuan menyatakan perasaan. ${ }^{20}$

b. Pendidikan Karakter Menulis

Dalam pendidikan karakter, terdapat nilai-nilai yang melatar belakangi lahirnya pendidikan karakter, salah satunya yakni kreatif, maksudnya yakni berfikir dan melakukan sesuatu untuk menghasilkan cara atau hasil baru dari sesuatu yang telah dimiliki. ${ }^{21}$

Dalam konsep literasi, menulis merupakan proses berulang yang dilakukan penulis untuk merevisi ide-idenya, mengulangi tahapan-tahapan menulis, hingga mampu mencurahkan ide dan gagasan tersebut dalam sebuah bentuk tulisan yang sesuai dengan gagsan atau ide yang dikembangkannya. Adapun tahap-tahap yakni terdapat tahap pemerolehan ide, pengolahan ide, pemrokdusian ide serta tahap penyuntingan dan tahap publikasi. Menulis bertujuan agar kegiatan menulis digunakan sebagai sarana memahami teks atau konsep keilmuan tertentu, serta bertujuan agar anak mampu menghasilkan berbagai jenis tulisan dengan konteks keilmuan,jenis tulisan, tujuan penulisan, dan sasaran pembacanya dengan tepat dan da baik. ${ }^{22}$

c. Pendidikan Karakter Berbicara

Nilai-nilai di dalam pendidikan karakter salah satunya terdapat bersahabat/komunikatif, maksudnya tindakan yang memperlihatkan

19 Neng Gustini, Dede Rohaniawati, Anugrah Imani, Budaya Literasi Model Pengembangan Budaya Baca Tulis Berbasis kecerdasan Majmuk Melalui Tutor Sebaya, (Yogyakarta:2012, CV Budi Utama), 5-18.

20 Susilawati, Noni Marlianingsih, mengembangkan minat baca dan pendidikan karakter melalui gerakan literasi sekolah, jurnal ilmiah kependidikan, Vol. 5, No. 3 November 2018, 194-195.

${ }^{21}$ Retno Listyarti, Pendidikan Karakter dalam Metode Aktif, Inovatif, dan Kreatif, 6.

22 Yunus Abidin,Tita Mulyani, Hana Yunansah, Pembelajaran Literasi, 206-213. 
rasa senang berbicara, bergaul, dan bekerja sama dengan orang lain. 23

Menurut Tarigan, berbicara adalah kemampuan mengucapkan bunyi-bunyi artikulasi atas kata-kata untuk mengekspresikan, menyatakan, serta menyampaikan pikiran, gagasan, dan perasaan. Sedangkan James A.F, Stones menyebutkan bahwa komunikasi adalah proses dimana seseorang berusaha memberikan pengertian dengan cara pemindahan pesan. Adapun definisi yang efektif yakni menyampaikan sesuatu dengan cara yang tepat dan jelas sehingga informasi yang kita sampaikan dapat dengan mudah dimengerti oleh orang lain. Komunikasi efektif menjadi salah satu hal yang penting di mana komunikator dapat menyampaikan pesannya secara baik dengan menggunakan media yang tepat dan dapat diterima oleh sasaran yang tepat. 24 Adapun tujuan berbicara yaitu: informatif, rekreatif, persuasif dan argumentatif. Adapun berdasarkan metode penyampaian berbicara ada 4 jenis berbicara, yaitu metode mendadak, metode tanpa persiapan, metode membaca naskah, dan metode menghafal. 25

Berbicara secara sederhana dibagi menjadi dua kategori, yaitu bicara publik dan bicara interpersonal.

a. Berbicara di depan publik

Berbicara didepan publik memiliki ciri-cirikhusus di antaranya adalah jarak antara pembicara dengan pendengarnya yang berjumlah banyak, ada pembagian waktu bicara yang jelas antara pembicara yang berada di depan panggung dengan pendengarnya.

b. Berbicara interpersonal

${ }^{23}$ Retno Listyarti, Pendidikan Karakter dalam Metode Aktif, Inovatif, dan Kreatif, 7.

24 Hoirun Nisa', Komunikasi yang efektif dalam pendidikan karakter, jurnal universum, Vol. 10, No. 1 Januari 2016, 51.

25 Yunus Abidin,"Pembelajaran Bahasa Berbasis Pendidikan Karakter", (Skripsi, Universitas Islam Negeri Surabaya, Surabaya, 2013), 13-18. 


\section{AL-ADABIYAH: Jurnal Pendidikan Agama Islam}

Secara sederhana, pengertian berbicara interpersonal adalah pembicara santai dengan beberapa orang. Ada lima perbedaan antara berbicara interpersonal dengan berbicara di depan publik.

a) Tidak ada jarak antara pihak-pihak yang berbicara

b) Tidak adayang secara spesifik diposisikan sebagai pembicara atau narasumber

c) Tidak ada pembagian sesi pada saat berbicara

d) Suasana lebih mengutamakan keakraban (friendly)

e) Responsif, tingkat kecepatan menggapai pembicaraan bersifat langsung tanpa jeda. ${ }^{26}$

Dapat kita ketahui bahwa pendidikan karakter dalam berkomunikasi atau berbicara tersebut secara tidak langsung dapat membentuk karakter anak, dengan berbicara yang luwes dan terstruktur, anak lebih mudah dalam mengolah kata-kata yang diucapkan serta membuat dirinya menjadi semakin percaya diri untuk berbicara atau berkomunikasi dimana saja dan bersama siapa saja, hal tersebut akan membentuk penddikan karakter terhadap anak tersebut.

\section{Metode}

Penelitian ini menggunakan pendekatan kualitatif deskriptif. Pendekatan kualitatif adalah prosedur penelitian yang menghasilkan data deskriptif baik berupa tulisan maupun lisan dari orang-orang dan perilaku yang dapat diamati. Dalam penelitian kualitatif metode yang biasa dimanfaatkan yaitu wawancara, observasi, dan dokumentasi. ${ }^{27}$ Dalam penelitian kualitatif instrumennya adalah orang atau human instrument,

26 Bayu Krisna, Mendulang Rupiah Lewat Kemampuan Berbicara, (Jakarta selatan: PT. Tangga Pustaka), 2008, 3-5.

27 Lexy J.Moleong. Metode Penelitian Kualitatif, (Bandung:PT Remaja Rosdakarya, 2017), 4-6. 


\section{AL-ADABIYAH: Jurnal Pendidikan Agama Islam}

yaitu pendiri itu sendiri, metode kualitatif digunakan untuk mendapatkan data yang mendalam. ${ }^{28}$

Jenis penelitian yang digunakan di dalam penelitian ini adalah penelitian kualitatif yang bersifat fenomenologi, dengan alasan karena data penelitian yang akan dikumpulkan berupa kata-kata, gambar, dan bukan angka serta menarik untuk diteliti karena hal tersebut memang benar adanya. Dengan demikian laporan penelitian akan berisi kutipan data untuk memberikan gambaran terkait fakta-fakta maupun fenomena yang akan diteliti. Sedangkan informan di Kampong Batja adalah: RT/RW adalah bapak Suhadi. Pendiri Kampoeng Batja adalah Kung Iman Suligi. Pengunjung Kampoeng Batja adalah Alwin Gwhozali, Aisyah Ruch Illahi, Azzahrah Aulia Dikarunia, Bintang Mega Sulistyo Suciati. Relawan Kampoeng Batja adalah Aniq Mayya Rosya, Novi Kamelia dan Vivi. Masyarakat sekitar Kampoeng Batja adalah Suharjo dan Khomsah.

\section{Hasil dan Diskusi}

\section{Budaya Literasi dalam Pembentukan Karakter Membaca Anak di Kampoeng Batja Patrang Jember}

Budaya literasi merupakan kegiatan membaca dan menulis yang terdapat di Kampoeng Batja . Budaya ini merupakan melatih kebiasaan anak yang berada di sekitar Kampoeng Batja dan sekitarnya dalam hal membaca secara bervariatif. Dengan adanya budaya literasi tersebut keterampilan dan karakter anak sedikit demi sedikit akan terbentuk, sehingga melatih anak untuk terbiasa membaca buku dan membaca keadaan disekitarnya.

Dengan adanya budaya literasi tersebut karakter membaca pada anak akan terbentuk sedikit demi sedikit. Kegiatan literasi di Kampoeng Batja meliputi membaca Al-Qur'an, buku cerita, buku islami dan buku-buku yang lainnya. Adapun kegiatan membaca disana juga diajarkan berlatih membaca cepat dengan media gambar. Sehingga kegiatan tersebut dapat 2017), 8

28 Sugiyono, Metode Penelitian Kualitatif, Kualitatif dan R\&D, (Bandung:Alfabeta, 


\section{AL-ADABIYAH: Jurnal Pendidikan Agama Islam}

menumbuhkan keterampilan dan pembentukan karakter religius anak, yang awalnya anak tersebut kurang minat dalam membaca dengan adanya kegiatan yang sangat berfariatif, anak tersebut pasti akan tertarik untuk mengikutinya. Menurut Ma'mur, membaca merupakan kegiatan rutin yang tidak dapat dipisahkan dari gaya kehidupan manusia modern, terlebih lagi dalam dunia pendidikan, adapun membaca merupakan sebuah proeses interaktif yang berlangsung antara pembaca dan teks, sehingga dengan membaca anak dapat memperoleh banyak wawasan yang baru serta dapat lebih meningkatkan keterampilan membaca pada anak tersebut. Adapun jenis-jenis dari membaca terdapat empat jenis membaca, diantara nya yakni membaca reseptif, membaca reflektif, membaca skimming dan scanning. ${ }^{29}$

Adapun dari definisi tersebut dapat dilihat bahwa menemukan makna dari bacaan tulisan adalah tujuan utama membaca dan bukan mengenai huruf-huruf. Membaca bersuara sering juga digunakan untuk membacakan puisi dan pantun. Adapun membaca reseptif dilakukan pada saat membaca narasi. Adapun dari teori tersebut sesuai dengan pernyataan dari pendiri Kampoeng Batja, yang menyatakan bahwa membaca itu sebenarnya juga bisa menjadi media yang mujarab untuk mengembangkan karakter anak, terutama pada karakter religius anak. Kita bisa melatih kemampuan membaca kalimat pendek saja lebih dahulu dengan memperhatikan buku serta intonasinya. Tentu untuk anak ini akan dengan sendirinya menghayati apa yang mereka baca jika sudah sesuai dengan yang ia inginkan, dan tentunya kalimat yang diberikan haruslah kalimat yang bermuatan aspek afeksi, sehingga suasana anak bisa terbawa untuk menghayatinya. Pada tingkatan berikutnya bacaan bisa diarahkan pada cerita yang dibawakan dengan membaca nyaring menggunakan pendekatan yang sesuai dengan masing-masing karakter anak, dengan pendekatan tersebut anak dapat mencermati, empati, kekayaan imajinasidapat tebentuk dan dengan pembiasaan seperti itulah kecerdasan anak akan bertumbuh lebih baik.

29 Neng Gustini, Dede Rohaniawati, Anugrah Imani, Budaya Literasi, 5-18. 


\section{AL-ADABIYAH: Jurnal Pendidikan Agama Islam}

Secara spesifik, pendidikan karakter membaca yang berbasis religius juga diterapkan dengan adanya kegiatan membaca A1-Qur'an. Membaca alqur'an tersebut termasuk membaca reflektif yakni membaca dengan dengan penuh penghayatan dalam setiap kata dan kalimat yang dibacanya, seperti dibaca dengan menggunakan tartil, qirah ataupun murojaah biasa. Terkadang ada juga dengan membaca reflektif untuk mengetahui berapa hasil dari kalimat yang ia baca seperti membaca kalimat dalam soal matematika.

Adapun membaca skimming dan scanning yang terdapat didalam kegiatan disana yakni dengan membaca buku bacaan yang meliputi agama seperti membaca buku tentang kisah-kisah walisongo, nabi-nabi, aqidah akhlak, fikih, sejarah kebudayaan islam, serta buku-buku islami lainnya yang kemudian hasilnya dijadikan sebagai tulisan.

Menurut informasi dari beberapa pihak yang telah peneliti wawancarai, dapat diketahui bahwa kegiatan membaca di Kampoeng Batja berjalan dengan baik dan kegiatan tersebut tentunya juga sangat menyenangkan dan menarik anak-anak untuk mengikuti kegiatan-kegiatan selanjutnya. Membaca menambah kosa kata dan pengetahuan akan tata bahasa dan sintaks, yang penting lagi membaca mempekenalkan kita pada banyak ragam ungkapan kreatif, dan dengan demikian memepertajam kepekaan linguistik dan kemampuan menyatakan perasaan. 30

Berdasarkan temuan data dilapangan sesuai dengan teori diatas bahwa karakter membaca anak dapat terbentuk melalui kegiatan-kegiatan membaca seperti membaca reseptif, reflektif, skimming dan scanning. Dengan adanya bervariasai nya membaca anak tersebut tidak merasa bosan dan tidak lagi malas dalam membaca,karena mereka membacanya sesuai dengan keterampilan dan kemampuan mereka masing-masing, dan tidak karena terpaksa.

30 Susilawati, Noni Marlianingsih, mengembangkan minat baca dan pendidikan karakter melalui gerakan literasi sekolah, jurnal ilmiah kependidikan, Vol. 5, No. 3 November 2018, 194-195. 


\section{AL-ADABIYAH: Jurnal Pendidikan Agama Islam}

Adapun kegiatan di Kampoeng Batja sangat didukung penuh oleh masyarakat di sekitarnya, sehingga dengan adanya kegiatan di Kampoeng Batja sangatlah mendorong masyarakat serta anak-anak untuk ikut melaksanakan kegiatan tersebut dengan sebaik-baiknya, masyarakat disana juga membudayakan membaca dengan tersedianya pojok baa yang terdapat di rumah-rumah masyarakat seperti pojok baca salon, pojok baca lansia serta pojok baca diniyah.

\section{Budaya Literasi dalam Pembentukan Karakter Menulis Anak di Kampoeng Batja Patrang Jember}

Budaya membaca dan menulis dikalangan anak-anak dan guru kini sedang digalakkan melalui program-program literasi yang terdapat di masyarakat. Dalam situasi yang seperti ini ketika anak-anak hanya menjadi pelaku komunikasi yang pasif. Kondisi seperti ini dapat terlihat ketika anakanak bercerita tentang perjalanannya dari rumah ke sekolah atau bercerita tentang pengalamannya di masyarakat sekitarnya, semua yang dilihat dialaminya dapat diceritakan dalam bahasa lisan, ketika disuruh menulis pengalamnnay dari rumah sampai sekolah anak sudah mulai kebingungan.

Greene dan Petty menjelaskan bahwa menulis kreatif merupakan suatu kegiatan mengarang yang sifatnya personal dan tidak selamanya mempunyai kegiatan praktis. ${ }^{31}$ Pembelajaran menulis merupakan salah satu gaya belajar yang unik. enulis menekankan pada proses dan hasil. Hal ini menunjukkan bahwa menulis tidak serta merta dimiliki oleh seseorang akan tetapi memerlukan waktu untuk menghasilkan.

Berdasarkan temuan data dilapangan sesuai dengan teori diatas bahwa menumbuhkan karakter menulis anak melalui kegiatan tulis menulis yang diadakan di Kampoeng Batja memiliki beberapa tahap dalam menulis yaitu:

a. Pemerolehan ide

31 Mimin Ninawati, "Efektivitas Model Pembelajaran Literasi Kritis Berbasis Pendekatan Konsep Untuk meningkatkan Menulis Kreatif Siswa Sekolah Dasar", Jurnal Ilmiah Pendidikan Dasar, Vol. IV No. 1, Juni 2019, hal. 69-70. 
Dalam tahapan memperoleh ide, seorang penulis harus menguasai konsep tertentu yang akan ditulisnya. Upaya mengembangkan pemahaman konsep ini dapat penulis lakukan dengan beberapa cara antara lain membaca, meneliti, maupun berdialog/wawancara dengan pakar. Upaya ini harus dilandasi oleh motivasi intrinsik yang kuat dalam diri penulis tersebut, agar mampu menulis dengan fokus dan tuntas. ${ }^{32}$

Peneliti dapat mengambil kesimpulan bahwa pemerolehan ide itu dapat langsung dibentuk dengan kebiasaan anak menulis, meskipun hanya menulis tentang pengalaman dari kehidupannya sendiri, dan memerlukan suasana yang tenang dalam menulis, karena untuk mencari ide dan menyusun sebuah kalimat untuk ditulis tidakklah mudah, anak-anak melakukan kegiatan pemerolehan ide tersebut ketika mereka melaksanakan kegiatan menulis pengalaman mereka masing-masing di kertas yang telah disediakan, dsitulah mereka dapat sesuka mereka membuat sekreatif mungkin ide-ide dituangkan kedalam tulisan mengeenai tentang dirinya sendiri. Hal tersebut sungguh membuat anak-anak tertarik dan suka terhadap tulis menulis.

b. Tahap pengolahan ide

Pada tahap ini penulis akan mendayagunakan beberapa kemampuan yang meliputi kemampuan berfikir, kemampuan berasa, dan kemampuan berimajinasi, mereka akan menulis bebas sesuai dengan bahasa nya mereka sendiri. Adapun kegiatan yang terdapat di Kampoeng Batja sangat mendukung sekali dalam memeroleh pengolahan ide anak-anak karena kegiatan di Kampoeng Batja didesain sangat bervariatif, sehingga mereka tidak malu untuk mengesplorasi dirinya dengan teman-temannya.hal tersebut juga dapat membentuk karakter anak melalui menulis,karena dengan

32 Yunus Abidin,Tita Mulyani, Hana Yunansah, Pembelajaran Literasi, 206-213. 
menulis segala pemerolehan ide-ide atau gagasan akan tersampaikan dengan baik.

c. Tahap pemroduksian ide

Pada tahap ini dapat diaplikasikan pada kegiatan sinopsis, membuat pantun, membuat puisi, cerpen dan lain sebagainya. Hal tersebut dengan cara menulis sinopsis dari hasil buku yang telah mereka baca, menulis rangkuman dari materi yang telah dijelaskan oleh kakak-kakak disana, serta menulis variasi pantun dan puisi sesuai apa yang mereka inginkan. Dengan adanya kegiatan tersebut maka anak tidak jenuh dalam menulis karena materi-materi yang telah diberikan sesuai dengan apa yang mereka butuhkan.Dan kegiatan menulis tersebut tidak terikat di satu tempat untuk menulis, melainkan bertempat dengan bebas sesuka hati anak tersebut, dengan begitu anak-anak akan memperoleh banyak ide-ide yang bermunculan untuk dituangkan kedalam tulisan, dengan situasi dan kondisi yang sangat mendukung untuk mengekspresikan diri dalam bentuk tulisan.

d. Tahap penyuntingan

Pada tahap ini yang selalu memantau selama kegiatan tulis menulis berlangsung yakni relawan yang terdapat disana, dan yang membenarkan dari beberapa karya dari anak-anak agar hasil yang mereka peroleh dapat dibaca dengan menarik, dan di design dengan sebagus mungkin.

e. Tahap publikasi

Pada tahap ini anak-anak mempublikasikan hasil dari karya-karya mereka dengan menempelkan hasil karya nya di majalah dinding dan terdapat di pohon literasi juga, agar yang melihat menjadi antusias untuk membaca hasil karya dari anak-anak yang telah ditempelkan tersebut.

Adapun beberapa kegiatan tulis menulis anak yang terdapat di Kampoeng Batja yakni kegiatan yang berbasis religius seperti menulis 


\section{AL-ADABIYAH: Jurnal Pendidikan Agama Islam}

kaigrafi, menyambungkan ayat dengan menulisnya di kertas, menulis cerita cerita islami, menulis cerpen, menulis pantun, menulis sinopsis yang terdapat didalam buku, serta masih banyak lagi kegiatan yang berhubungan dengan tulis menulis yang lainnya. Hasil dari kegiatan menulis tersebut dapat dipublikasikan melalui mading, sosial media, dijadikan buku bacaan, pameran, dan lain sebagainya.

\section{Budaya Literasi dalam Pembentukan Karakter Berbicara Anak di Kampoeng Batja Patrang Jember}

Menurut Tarigan, berbicara adalah kemampuan mengucapkan bunyibunyi artikulasi atas kata-kata untuk mengekspresikan, menyatakan, serta menyampaikan pikiran, gagasan, dan perasaan. Sedangkan sebagai bentuk wujudnya berbicara disebut sebagai alat untuk mengkomunikasikan gagasan-gagasan yang disusun serta dikembangkan sesuai dengan kebutuhan-kebutuhan sang pendengar atau penyimak. ${ }^{33}$

Adapun tujuan berbicara sebagai menumbuhkan karakter anak, dan menyampaikan gagasan untuk membangun pengetahuan pendengar, serta memberikan kesan menyenangkan bagi diri pembicara dan pendengar.

Karakter berbicara memiliki peranan penting dalam upaya melahirkan generasi masa depan yang cerdas, kreatif, kritis dan berbudaya. Dengan menguasai keterampilan berbicara, siswa mampu mengekspresikan pikiran dan perasaannya secara cerdas sesuai materi dan situasi pada saat dia sedang berbicara. Karakter berbicara juga mampu membentuk generasi masa depan yang kkreatif sehingga mampu berbicara yang komunikatif, jelas. Runtut, mudah dipahami. Selain itu, karakter berbicara juga melahirkan keterampilan yang dapat membuat generasi masa depan yang kritis karena mereka memiliki kemampuan untuk mengekspresikan suatu gagasan, pikiran atau perasaan kepada orang lain secara runtut dan sistematis. Karakter berbicara juga mampu melahirkan generasi masa

33 Erwin putera permana, pengembangan media pembelajaran boneka kaki untuk meningkatkan keterampilan berbicara siswa kelas II sekolah dasar, jurnal profesi pendidikan dasar, Vol. 2,No. 2, Desember 2015, 134. 


\section{AL-ADABIYAH: Jurnal Pendidikan Agama Islam}

depan yang berbudaya karena sudah terbiasa dan terlatih untuk berkomunikasi baik kepada orang sekitar sesuai dengan materi dan situasi tutur pada saat berbicara.

Berdasarkan temuan data di lapangan bahwa anak-anak dapat berkomunikasi dengan sopan dan santun kepada masyarakat sekitar,serta memiliki etika yang bagus kepada orang-orang yang lebih tua dari mereka baik itu dilihat dari anak kecil hingga dewasa. Dan anak-anak dikampong batja tersebut sudah saling menghormati kepada masyarakat di lingkungannya maupun di luar lingkungannya. Pada kegiatan di Kampoeng Batja juga terdapat belajar berbicara di depan umum seperti membacakan puisi, membacakan pantun, membacakan hasil diskusinya. Kegiatan tersebut dilaksanakan karena agar anak-anak dapat terbiasa berbicara dengan bahasa yang baik dan benar serta sopan dan santun, dan menghilangkan rasa malu saat berbicara serta melatih anak untuk lebih tertata dalam berbicara. Maka dari itu dengan adanya budaya literasi di Kampoeng Batja sangat menunjang keterampilan anak serta dapat menumbuhkan karakter dalam berbicara dengan baik. Dengan adanya beberapa kegiatan yang melatih anak-anak untuk berbicara dengan benar merupakan bentuk stimulus agar dapat merubah sedikit karakter anak yang bersifat introvert.

Adapun berdasarkan metode penyampaian berbicara ada 4 jenis berbicara, yaitu metode mendadak, metode tanpa persiapan, metode membaca naskah, dan metode menghafal. ${ }^{34}$

Metode yang diterapkan di kegiatan Kampoeng Batja hanya metode membaca naskah dan metode menghafal, jika metode membaca naskah tersebut anak-anak menceritakan apa yang telah mereka tulis di buku mereka masing-masing seperti menceritakan pengalaman, menceritakan sinopsis yang terdapat dibuku, dan mereka menceritakannya dengan menghayati. Sedangkan metode menghafal itu biasanya anak-anak pada saat bulan ramadhan terdapat kegiatan menghafalkan surat-surat pendek

34 Yunus Abidin,"Pembelajaran Bahasa Berbasis Pendidikan Karakter", (Skripsi, Universitas Islam Negeri Surabaya, Surabaya, 2013), 13-18. 


\section{AL-ADABIYAH: Jurnal Pendidikan Agama Islam}

dan di setorkan kepada pengajarnya. Hal tersebut dapat meningkatkan keterampilan berbicara anak, serta menguatkan karakter berbicara anak.

Peneliti dapat menarik kesimpulan bahwa berbicara tersebut terdapat beberapa macam, dan hal ini sesuai dengan teori yang menyebutkan bahwa terdapat berbicara secara sederhana dibagi menjadi dua kategori, yaitu bicara publik dan bicara interpersonal.

a. Berbicara di depan publik

Berbicara didepan publik memiliki ciri-ciri khusus di antaranya adalah jarak antara pembicara dengan pendengarnya yang berjumlah banyak, ada pembagian waktu bicara yang jelas antara pembicara yang berada di depan panggung dengan pendengarnya.

b. Berbicara interpersonal

Secara sederhana, pengertian berbicara interpersonal adalah pembicara santai dengan beberapa orang. Ada lima perbedaan antara berbicara interpersonal dengan berbicara di depan publik.

1) Tidak ada jarak antara pihak-pihak yang berbicara

2) Tidak ada yang secara spesifik diposisikan sebagai pembicara atau narasumber

3) Tidak ada pembagian sesi pada saat berbicara

4) Suasana lebih mengutamakan keakraban (friendly)

5) Responsif, tingkat kecepatan menggapai pembicaraan bersifat langsung tanpa jeda. ${ }^{35}$

Berbicara dalam kategori di depan publik pada kegiatan di Kampoeng Batja diterapkan dengan baik melalui presentasi dari hasil diskusinya dan menjelaskan didepan teman-teman nya, setelah presentasi anak-anak diberikan kesempatan untuk bertanya tentang segala hal yang berkaitan dengan materi yang belum difahami, serta mendongeng dan membacakan puisi di depan, hal tersebut sangat mengajarkan kepada anak bahwa berbicara didepan umum tanpa merasa malu atau takut, dan secara tidak langsung pendidikan karakter berbicara anak dilatih dengan bertahap,

35 Bayu Krisna, Mendulang Rupiah Lewat Kemampuan Berbicara, 3-5. 


\section{AL-ADABIYAH: Jurnal Pendidikan Agama Islam}

yang awalnya anak tersebut malu untuk mengungkapkan gagasannya di depan umum dengan dijadikan sebagai sorotan utama, dengan demikian anak akan terbiasa untuk tampil dengan percaya diri.

Adapun berbicara interpersonal, juga diterapkan dengan sangat baik di Kampoeng Batja yakni dengan berbicara menyesuaikan kodisi yang ada disekitar, dengan cara tidak berbicara menggunakan bahasa yangsopan dan santun baik itu kepada orangtua atau pun kepada masyarakat sekitarnya, dan anak-anak di Kampoeng Batja tidak pernah berbicara yang terkesan durhana, hanya saja berbicara suara keras seperti biasanya saja tanpa membentak orang tersebut. Kemampuan berbicara menjadi point utama dalam membentuk karakter anak, karena karakter anak melalui berbicara biasanya dapat dijadikan sebagai tolak ukur oleh masyarakat, jika anak tersebut berbicara dengan sopan dan santun,maka respon dari masyarakat juga pasti akan baik, namun jika anak tersebut sudah berkata kasar dan mengungkapkan bahasa yang jorok, maka respon dari masyarakat dan sekitarnya juga akan buruk. Dan hal tersebut sangat menimbulkan efek jelek terhadap yang lainnya, oleh sebab itulah mengapa menumbuhkan karakter berbicara itu sangat penting sekali diterapkan, apalagi dalam masa anak-anak, yang mana mereka masih rentan terbawa arus oleh budayabudaya luar.

Pada kegiatan di Kampoeng Batja juga terdapat berlatih berbicara menggunakan bahasa inggris, jadi semisal ada orang luar datang ke Kmapoeng Batja, mereka bisa langsungmengasah keterampilan berbicara asing nya dengan orang tersebut, meski terkadang masih bertanya-tanya terlebih dahulu apa yang dimaksudnya. Namun hal tersebut juga mendukung untuk meningkatkan skill dan kepercayaan diri mereka, dan mereka dengan enjoy nya berbicara dengannya tanpa ada rasa malu ataupun takut, hal tersebut mungkin sudah terbiasa dilakukan oleh anakanak sehngga mereka tidak sampai dihantui oleh rasa ketakutan.

\section{Kesimpulan}




\section{AL-ADABIYAH: Jurnal Pendidikan Agama Islam}

Karakter membaca yang terbentuk melaui budaya literasi yang telah diterapkan di Kampoeng Batja adalah karakter membaca reseptif, reflektif, skimming dan scanning. Budaya literasi di Kampoeng Batja dapat membentuk karakter menulis cerita, menulis ayat-ayat Al-quran, menulis kaligrafi, menulis sinopsis, menulis pantun, kegiatan tersebut dilaksanakan dengan bernuansa keagamaan dimana hal tersebut diterapkan agar anakanak dapat mengembangkan kreativitas anak dan dapat melatih daya ingat anak. Karakter berbicara yang terbentuk melaui budaya literasi yang telah diterapkan di Kampoeng Batja adalah karakter berbicara di depan publik dan berbicara interpersonal.

\section{Referensi}

Abidin, Yunus, "Pembelajaran Bahasa Berbasis Pendidikan Karakter", Skripsi, Universitas Islam Negeri Surabaya, Surabaya, 2013.

Abidin, Yunus, dan Tita Mulyati, et. al, Pembelajaran Literasi Strategi Meningkatkan Kemampuan Literasi Matematika, Sains, Membaca, Dan Menulis, Jakarta: Bumi Aksara, 2018.

Gustini, Neng, Dede Rohaniawati, dan Anugrah Imani, Budaya Literasi Model Pengembangan Budaya Baca Tulis Berbasis Kecerdasan Majmuk Melalui Tutor Sebaya, Yogyakarta: Budi Utama, 2012.

Idi, Abudullah dan Safarina, Etika Pendidikan Keluarga, Sekolah Dan Masyarakat, Jakarta: Raja Grafindo Persada, 2016.

Krisna, Bayu, Mendulang Rupiah Lewat Kemampuan Berbicara, Jakarta Selatan: Tangga Pustaka, 2008.

Listyarti, Retno, Pendidikan Karakter dalam Metode Aktif, Inovatif, dan Kreatif, Jakarta: Erlangga, 2012.

Malawi, et. al., Ibadullah Pembelajaran Literasi Berbasis Sastra Lokal Magetan: Ae Media Grafika, 2017.

Moleong, Lexy J., Metode Penelitian Kualitatif, Bandung: Remaja Rosdakarya, 2017.

Muhammad, Maswari, Pendidikan Karakter Anak Bangsa, Jakarta: Baduose Media, 2011. 
Mursalim, "Penumbuhan Budaya Literasi dengan Penerapan Ilmu Keterampilan Berbahasa (Membaca dan Menulis)," Jurnal Fenomena, Vol. 3 No. 1 Juni 2017.

Ninawati, Mimin, "Efektivitas Model Pembelajaran Literasi Kritis Berbasis Pendekatan Konsep Untuk Meningkatkan Menulis Kreatif Siswa Sekolah Dasar", Jurnal Ilmiah Pendidikan Dasar, Vol. IV No. 1, Juni 2019.

Nisa', Hoirun, “Komunikasi yang Efektif dalam Pendidikan Karakter, Jurnal Universum, Vol. 10, No. 1 Januari 2016.

Permana, Erwin Putera, "Pengembangan Media Pembelajaran Boneka Kaki Untuk Meningkatkan Keterampilan Berbicara Siswa Kelas di Sekolah Dasar," Jurnal Profesi Pendidikan Dasar, Vol. 2,No. 2, Desember 2015.

Ratna, Nyoman Kutha, Peranan Karya Sastra, Seni, dan Budaya dalam Pendidikan Karakter, Yogyakarta: Pustaka Pelajar, 2014.

Riswandi, Ilmu Komunikasi, Yogyakarta: Graha Ilmu, 2009.

Salahudin, Anas dan Irwanto Alkrienciehie, Pendidikan Karakter Pendidikan Berbasis Agama Dan Budaya Bangsa, Bandung: Pustaka Setia, 2017.

Sugiyono, Metode Penelitian Kualitatif, Kualitatif Dan R\&D, Bandung: Alfabeta, 2017.

Susilawati, Noni Marlianingsih, "Mengembangkan Minat Baca Dan Pendidikan Karakter Melalui Gerakan Literasi Sekolah," Jurnal Imiah Kependidikan, Vol. 5, No. 3 November 2018, 194-195.

Syafaat, Aat dan Sohari Saharani, Dkk, Peranan Pendidikan Agama Islam Dalam Mencegah Kenakalan Remaja, Jakarta: Raja Grafindo, 2008.

Syahril, Akhmad, Pendidikan Karakter Berbasis Sistem Islamic Boarding School, Malang: Literasi Nusantara Abadi, T.T.

Thabrani, Abd. Muis Pengantar Dan Dimensi-Dimensi Pendidikan, Jember: STAIN Jember Press, 2013,

Tim Penyusun Kamus Bahasa, Kamus Bahasa Indonesia, Jakarta: Pusat Bahasa Departemen Pendidikan Nasional, 2008. 